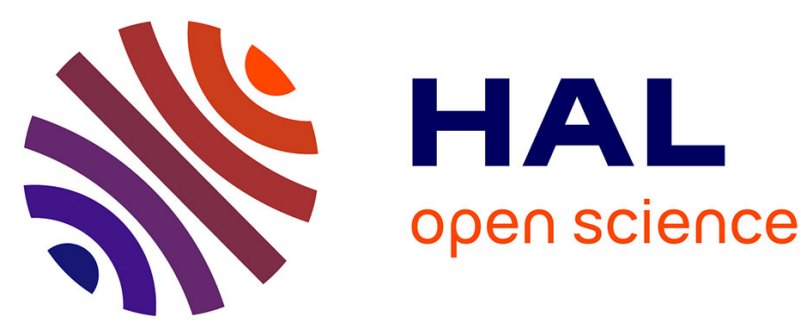

\title{
Respiratory toxicities of nanomaterials - A focus on carbon nanotubes
}

Jorge Boczkowski, Sophie Lanone

\section{To cite this version:}

Jorge Boczkowski, Sophie Lanone. Respiratory toxicities of nanomaterials - A focus on carbon nanotubes. Advanced Drug Delivery Reviews, 2012, 64 (15), pp.1694-1699. 10.1016/j.addr.2012.05.011 . inserm-03109121

\section{HAL Id: inserm-03109121 https://www.hal.inserm.fr/inserm-03109121}

Submitted on 13 Jan 2021

HAL is a multi-disciplinary open access archive for the deposit and dissemination of scientific research documents, whether they are published or not. The documents may come from teaching and research institutions in France or abroad, or from public or private research centers.
L'archive ouverte pluridisciplinaire HAL, est destinée au dépôt et à la diffusion de documents scientifiques de niveau recherche, publiés ou non, émanant des établissements d'enseignement et de recherche français ou étrangers, des laboratoires publics ou privés. 


\section{DETERMINANTS OF CARBON NANOTUBE TOXICITY}

\section{by}

Sophie Lanone $^{\text {a, b, c }}$, Pascal Andujar ${ }^{\text {a, b, c }}$, Ali Kermanizadeh ${ }^{\text {a, b }}$, Jorge Boczkowski ${ }^{\text {a, b, c, }}$ d, *

a Inserm U955, Equipe 4, Créteil, 94000, France.

${ }^{\mathrm{b}}$ Université Paris Est, Faculté de médecine, Créteil, 94000, France.

${ }^{\mathrm{c}}$ Centre Hospitalier Intercommunal, Service de pneumologie et pathologie professionnelle, Créteil, 94000, France.

${ }^{d}$ AP-HP, Hôpital Henri Mondor, Service de Physiologie Explorations Fonctionnelles, 94010 Créteil, France.

* corresponding author

* Corresponding author:

Jorge BOCZKOWSKI, MD, PhD.

Unité Inserm 955, Equipe 4

Faculté de Médecine de Créteil

8, rue du Général Sarrail

94000 Créteil

Phone: +33149813658

Fax: +33149813725

Email: Jorge.boczkowski@inserm.fr 



\begin{abstract}
In the last few years questions have been raised regarding the potential toxicity of carbon nanotubes $(\mathrm{CNT})$ to human and environment. It is believed that the physico-chemical characteristics of these materials are key determinants of CNT interaction with living organisms, and hence determine their toxicity. As for other nanomaterials, the most important of these characteristics are the length, diameter, surface area, tendency to agglomerate, biodurability, presence and nature of catalyst residues as well as chemical functionalization of the CNT. This review highlights the recent advancements in the understanding of the CNT properties which are essential in determining CNT toxicity. Hence the focus is on CNT dimensions, surface properties, bio-durability and corona formation as these fields have evolved greatly in recent years.
\end{abstract}

A deeper understanding of these events and their underlying mechanisms could provide a molecular explanation of the biological and physiological responses following CNT administration and therefore help in the development of safe by design materials.

Keywords: Carbon nanotubes, dimensions, surface properties, protein corona, durability. 